\title{
ANALISIS PENGARUH KECERDASAN INTELEKTUAL, KECERDASAN EMOSIONAL DAN KECERDASAN SPIRITUAL TERHADAP PERILAKU PEGAWAI \\ (Studi Kasus: Badan Kependudukan Keluarga Berencana Nasional Kota Palembang)
}

\author{
Nisa' Ulul Mafra \\ Fakultas Ekonomi, Universitas PGRI Palembang \\ Email: nisaulul29@univpgri-palembang.ac.id \\ Reina Damayanti \\ Fakultas Ekonomi, Universitas PGRI Palembang \\ Email: reinadamayanti.rd@univpgri-palembang.ac.id
}

DOI: http://dx.doi.org/10.35908/jeg.v5i1.949

\begin{abstract}
This study is entitled Analysis of the Effects of Intellectual Intelligence, Emotional Intelligence and Spiritual Intelligence on Employee Behavior with a Case Study: National Population Planning Board / BKKBN of Palembang City. Knowing the effect of intellectual, emotional and spiritual intelligence on employee behavior is the aim of this study. The research method used is multiple regression model. Data sources are primary data and secondary data. The research instrument uses a random sampling technique, with a population as well as a sample of 85 BKKBN Palembang City employees. The results showed that employee behavior is influenced by the three intelligences. This is evidenced by the results of the $t$ test of each intelligence (spiritual: 2,465, emotional: 2,155 and spiritual: 8,267) and $F$ test $(31,065)$. While the test of the coefficient of determination $(r 2)$ of 0.535 or $53.5 \%$ and the remaining $46.5 \%$ is influenced by other factors not included in this study, such as rewards, compensation and others. The correlation coefficient is 0.731 . This means that these three intelligence variables affect employee behavior and have a strong direct relationship.
\end{abstract}

Keywords: Intellectual Intelligence, Emotional Intelligence Spiritual Inteliigence, Employee Behavior

\begin{abstract}
ABSTRAK
Penelitian ini berjudul Analisis Pengaruh Kecerdasan Intelektual, Kecerdasan Emosional dan Kecerdasan Spiritual Terhadap Perilaku Pegawai dengan Studi Kasus: Badan Kependudukan Keluarga Berencana Nasional/BKKBN Kota Palembang. Mengetahui pengaruh kecerdasan intelektual, emosional dan spiritual terhadap perilaku pegawai merupakan tujuan penelitian ini. Metode penelitian yang digunakan adalah multiple regresssion model. Sumber data yaitu data primer dan data skunder. Adapun instrumen penelitian ini menggunakan random sampling technique, dengan jumlah populasi sekaligus sebagai sampel sebanyak 85 orang pegawai BKKBN Kota Palembang. Hasil penelitian menunjukkan perilaku pegawai dipengaruhi oleh ketiga kecerdasan tersebut. Hal ini dibuktikan dengan hasil uji t masing-masing kecerdasan ( spiritual : 2,465, emosional: 2,155 dan spiritual: 8,267) dan uji $F$ (31,065). Sedangkan uji dari koefisien determinasi $\left(r^{2}\right)$ sebesar 0,535 atau 53,5\% dan sisanya sebesar 46,5\% dipengaruhi oleh faktor lain yang tidak termasuk dalam penelitian ini, seperti penghargaan, kompensasi dan lain-lain. Koefisien korelasi sebesar 0,731. Artinya ketiga variabel kecerdasan ini mempengaruhi perilaku pegawai dan mempunyai hubungan yang kuat searah.
\end{abstract}

Kata Kunci: Kecerdasan Intelektual, Emosional, Spiritual, Perilaku Pegawai

\section{Pendahuluan}

Kemampuan dalam menghadapi dan beradaptasi terhadap situasi atau lingkungan baru secara tepat dan efektif dapat disimbolkan dengan istilah kecerdasan. Kecerdasan dianggap sebagai 
akal budi yang berkembang secara sempurna dan identik dengan kecerdikan atau kepintaran, cepat bereaksi ketika ada masalah serta cepat respon ketika mendapat informasi. Sehingga Daryanto (2006:141) mendefinisikan kecerdasan sebagai kemampuan seseorang untuk memecahkan masalah yang dihadapi, dalam hal ini adalah masalah yang menuntut kemampuan fikiran. Kecerdasan bukan saja diperlukan untuk mampu menjawab permasalahan atau pertanyaan yang muncul dalam perkembangan hidup tapi juga perkembangan organisasi karena sumber daya manusia (SDM) tersebut berperan sebagai salah satu motorik organisasi sangat memerlukan kecerdasan yang ada padanya.

Ada banyak kecerdasan yang ada pada diri manusia, seperti kecerdasan intelektual, kecerdasan emosional dan kecerdasan spiritual. Sunar (2010:160) mendefinisikan kecerdasan intelektual yaitu:

"Kecerdasan Intelektual
sebagai kemampuan untuk
bekerja secara abstrak, baik
menggunakan ide-ide, simbol,
hubungan logis, maupun
konsep-konsep teoritis,
termasuk kemampuan untuk
mengenali dan belajar serta
menggunakan abstraksi
tersebut dan kemampuan
untuk menyelesaikan masalah
termasuk masalah yang baru".

Mengenai kecerdasan emosional, Carter (2010: 1) menyatakan bahwa:

$\begin{array}{lrr}\text { “Orang yang memiliki soft } \\ \begin{array}{l}\text { competency } \\ \text { kecerdasan }\end{array} & \text { atau disebut } \\ \text { emosional }\end{array}$

\begin{abstract}
(Emotional Intelligence) yang sering diukur sebagai Emotional Intelligent Quotient (EQ), adalah kemampuan menyadari emosi diri sendiri dan emosi orang lain"
\end{abstract}

. Masih menurut Carter ada dua aspek utama EQ adalah: 1) Memahami diri, tujuan, cita-cita, respon, dan perilaku anda dan 2) Memahami orang lain dan perasaan mereka. Orang yang cerdas secara emosi tidak selalu identik dengan bersikap ramah tetapi bisa bersikap tegas dan tegar serta apa adanya. walaupun terkadang hal tersebut tidaklah selalu menyenangkan dan mampu bertindak jujur dengan mengungkapkan kebenaran. Artinya harus bisa memanage emosi dengan tidak menyerahkan semuanya kepada perasaan ketika bertindak tetapi tetap menggunakan fikiran agar terekspresikan secara efektif yang pada akhirnya membuat orang merasa nyaman bekerja sama untuk mencapai tujuan bersama.

Kecerdasan spiritual merupakan kecerdasan tertinggi karena dapat memfungsikan kecerdasan intelektual dan kecerdasan emosional secara efektif. Karena itulah Zohar \& Marshal (2014:105) mendefinisikan:

"Kecerdasan spiritual sebagai
kecerdasan untuk menghadapi
persoalan makna atau value,
yaitu kecerdasan untuk
menempatkan perilaku dan hidup
kita dalam konteks makna yang
lebih luas dan kaya".

Seseorang yang memiliki kecerdasan yang tinggi secara intelektual, emosional dan spiritual diharapkan berperilaku baik sehingga mampu memecahkan masalah 
dan menjawab pertanyaan yang ada sekaligus memberi solusi terhadap permasalahan yang muncul. Juga mampu mengendalikan diri terutama ketika ada tekanan, jernih ketika berfikir, penuh kreatifitas, mampu mengelola keberagaman situasi dan menjaga amanah yang ada, memiliki rasa empati dan penuh percaya diri. Jika semua hal di atas dapat dikelola dengan baik sehingga tidak ada lagi pegawai yang melakukan distorsi, ketidakjujuran serta memanipulasi pekerjaan maka secara otomatis akhirnya berdampak yang sangat baik terhadap kinerja pegawai dan organisasi.

Semua kecerdasan diatas akan membawa pengaruh terhadap perilaku seseorang, karena reprentasi perilaku sebagai gambaran dari hal yang terdapat dalam dirinya. Sebagaimana Prawirosentono (2011:35) menjabarkan definisi perilaku, yaitu:

"Perilaku sebagai suatu
karakteristik penting dari pribadi
untuk melakukan kegiatan.
Perilaku merupakan hasil
gabungan dari berbagai faktor
psikologis seperti faktor fisik,
biologis, dan kondisi sosial yang
mempengaruhi lingkungan
kehidupan seseorang"

Artinya jika perilaku seseorang baik maka akan membawa hal yang baik pada atmosfir organisasi, begitu pula jika pegawai berperilaku tidak baik. Tentu saja yang mendapat imbasnya adalah perusahaan atau instansi tempat bekerja.

Semua perusahaan ataupun instansi sangat membutuhkan hal di atas, begitu pula dengan Kantor Badan Kependudukanan Keluarga Berencana Nasional (BKKBN) Kota Palembang yang merupakan instansi pemerintah, yang melaksanakan tugas negara sebagai bentuk pelayanan kepada orang banyak yang ingin mewujudkan visi misi yang dimiliki. Visi kantor BKKBN menjadi lembaga yang handal dan dipercaya dalam mewujudkan penduduk tumbuh seimbang dan keluarga berkualitas. Sedangkan misinya, mengutamakan pembangunan berwawasan kependudukan, menyelenggarakan keluarga berencana, memfasilitasi pembangunan keluarga, membangun dan menerapkan budaya kerja organisasi secara konsisten.

Hasil survey awal, ada beberapa fenomena yang terjadi pada Kantor Badan Kependudukan dan Keluarga Berencana Nasional (BKKBN) Kota Palembang seperti masih ada pekerjaan yang seharusnya bisa diselesaikan tepat waktu, kurangnya kekompakan dan keakraban antar pegawai, kurang bisa mengendalikan emosi ketika menghadapi masalah dalam pekerjaan terutama untuk pekerjaan yang deadline, disiplin waktu kurang tepat seperti yang terlihat dari waktu jam istirahat dan ketika jam masuk kembali.

Hal yang terjadi pada Kantor Badan Kependudukan dan Keluarga Berencana Nasional (BKKBN) Kota Palembang inilah yang menarik minat untuk melakukan penelitian yang sama dengan tujuan:

1. Untuk mengetahui pengaruh kecerdasan intelektual terhadap perilaku Pegawai Badan Kependudukan dan Keluarga Berencana Nasional (BKKBN) Kota Palembang.

2. Untuk mengetahui pengaruh kecerdasan emosional terhadap perilaku Pegawai Badan Kependudukan dan Keluarga Berencana Nasional (BKKBN) Kota Palembang.

3. Untuk mengetahui pengaruh kecerdasan spiritual terhadap perilaku Pegawai Badan Kependudukan dan 
Keluarga Berencana Nasional (BKKBN) Kota Palembang.

4. Untuk mengetahui pengaruh kecerdasan intelektual, emosional dan spiritual terhadap perilaku Pegawai Badan Kependudukan dan Keluarga Berencana Nasional (BKKBN) Kota Palembang.

Penelitian serupa telah banyak dikaji seperti yang dilakukan oleh Kusumawati (2015), Wulantika dan Buhari (2015), Haryoko dkk (2018) Firdaus dkk (2019), Hidayah (2019) dan Putri (2016) Semua hasil penelitian menyatakan bahwa kecerdasan intelektual, emosional dan spiritual berpengaruh terhadap perilaku maupun kinerja pegawai. Semakin tinggi kecerdasan yang dimiliki pegawai akan semakin baik atau tinggi pula perilaku atau kinerja yang dapat dicapai.

\section{Metode Penelitian}

Penelitian asosiatif adalah metode yang dianggap paling sesuai dengan kajian penelitian ini karena dapat mengetahui kolektivitas pengaruh variabel independen terhadap variabel dependen sehingga dapat membantu dalam menyelesaikan penelitian ini. Sedangkan jumlah populasi sekaligus sampel digunakan sama yaitu seluruh Aparatur Sipil Negara (ASN) di Kantor Badan kependudukan dan keluarga berencana (BKKBN) Kota Palembang berjumlah 85 pegawai.

Untuk mendapatkan data yang tepat dan akurat dapat dilakukan dengan mengumpulkan berbagai macam sumber data, seperti data primer dan sekunder (Sugiyono,2018:225). Data primer diperoleh dengan mengumpulkan jawaban responden tentang sebaran kuesioner peneliti dalam hal ini pegawai Kantor Badan kependudukan dan keluarga berencana (BKKBN) Kota
Palembang, sedangkan data sekunder biasanya tersedia dan dikumpulkan oleh pihak lain, misalnya dokumentasi mengenai diri pegawai bahkan literasi buku yang relevan dengan penelitian dimaksud.

Selanjutnya penyebaran kuesioner dan pengumpulan dokumen merupakan hal biasa yang untuk memperoleh data yang diperlukan. Kuesioner adalah pengumpulan data yang diwakili oleh daftar pertanyaan/pernyataan yang sudah disusun secara cermat terlebih dahulu dan dokumentasi yaitu berupa rekapitulasi personalia, struktur organisasi, peraturanperaturan, riwayat perusahaan dan sebagainya (Sanusi,2014:109). Cara inilah yang dilakukan untuk memperoleh data yang dibutuhkan dalam penelitian ini.

Langkah selanjutnya yang dilakukan adalah menguji instrumen (kuesioner) yang meliputi: 1) Uji validitas, adalah suatu instrumen yang digunakan untuk mengetahui seberapa tepat suatu alat ukur dapat melakukan fungsinya dan 2) Uji reliabilitas, sebagai alat untuk mengukur suatu kuesioner yang merupakan indikator dari variabel konstruks yang akan mendapatkan hasil yang sama jika dilakukan pengukuran ulang (Priyatno,2018:25). Kriteria pengujian reliabilitas dengan membandingkan Cronbach's Alpha dengan 0,60 (Sujarweni,2014:193).

Setelah melewati uji instrumen dilanjutkan pada tahap berikutnya dengan menggunakan beberapa teknik analisis (Ghozali,2011:160): pertama, Uji normalitas yaitu data yang bertujuan untuk menguji apakah data yang akan digunakan dalam model regresi berdistribusi normal atau tidak. Normalitas data merupakan hal yang penting karena dengan data yang terdistribusi normal, maka data tersebut dianggap dapat mewakili populasi. Kedua, 
Uji Multikolinieritas untuk memastikan ada tidaknya korelasi antar variabel bebas. Ada pedoman umum (rule of thumb) untuk batasan nilai VIF dan tolerance agar model regresi terbebas dari persoalan multikolinearitas yaitu dibawah 10 untuk VIF dan diatas $10 \%$ untuk tolerance. Ketiga, Uji Heteroskedastisitas yang bertujuan untuk mengetahui apakah dalam model regresi terjadi ketidaksamaan varians dan residual pengamatan yang lain dengan dasar pengambilan keputusan

\section{Metode Analisis}

Metode analisis regresi berganda (Priyatno,2018:107) merupakan salah satu metode kuantitatif digunakan untuk menganalisis data yang diperoleh, di mana metode ini merupakan suatu metode analisis data yang menggunakan angkaangka agar pemecahan masalah dapat dilakukan secara pasti dengan perhitungan matematik. Tujuannya untuk mengetahui pengaruh kecerdasan Intelektual, emosional dan spiritual terhadap perilaku pegawai Badan Kependudukanan Keluarga Berencana Nasional (BKKBN) Kota Palembang yang dihitung dengan rumus:

$$
\mathrm{Y}=\alpha+\mathrm{b}_{1} \mathrm{X}_{1}+\mathrm{b}_{2} \mathrm{X}_{2}+\mathrm{b}_{3} \cdot \mathrm{X} 3+\varepsilon
$$

Dimana:

$$
\begin{array}{ll}
\mathrm{Y} & =\text { Perilaku Pegawai } \\
\alpha & =\text { Konstanta } \\
\mathrm{b}_{1}, \mathrm{~b}_{2}, \mathrm{~b} 3 & =\text { Koefisien Regresi } \\
\mathrm{X}_{1} & =\text { Kecerdasan intelektual } \\
\mathrm{X}_{2} & =\text { Kecerdasan emosional } \\
\mathrm{X}_{3} & =\text { Kecerdasan spiritual } \\
\boldsymbol{\varepsilon} & =\text { Error Term }
\end{array}
$$

\section{Pembahasan}

\section{a. Karakteristik Responden}

Ada beberapa karakteristik yang melekat pada diri responden sebagai penunjang keabsahan dari data kuesioner yang diberikan, yaitu:

Karakteristik Berdasarkan Jenis Kelamin

Sebagian besar responden yang berjumlah 41 orang responden $(48,20 \%)$ berjenis kelamin laki-laki dan perempuan berjumlah 44 orang responden $(51,80 \%)$, dengan demikian dapat disimpulkan bahwa berdasarkan jenis kelamin Pegawai pada Badan Kependudukan dan Keluarga Berencana Nasional Kota Palembang dominan berjenis kelamin perempuan.

\section{Karakteristik Berdasarkan Usia}

Jumlah responden sebanyak 85 orang dengan tingkat usia antara 25-45 tahun sebanyak 38 orang $(44,80 \%)$, dan responden dengan tingkat usia 46-65 tahun sebanyak 47 orang $(55,20 \%)$, Dapat disimpulkan bahwa usia pegawai Badan Kependudukan dan Keluarga Berencana Nasional Kota Palembang dominan dengan tingkat usia $46-65$ tahun $(55,20 \%)$.

Karakteristik Berdasarkan Tingkat Pendidikan

Sebanyak 15 orang responden (17,60\%) berpendidikan SMA/SMK, 42 orang responden $(49,40 \%)$ berpendidikan S1 dan 28 orang $(33,00 \%)$ berpendidikan $\mathrm{S} 2$, dapat disimpulkan bahwa berdasarkan tingkat pendidikan pada Badan Kependudukan dan Keluarga Berencana Nasional Kota Palembang lebih banyak berpendidikan Strata I (S1).

\section{b. Pengujian Variabel Penelitian \\ Uji Validitas}

Membandingkan $\mathrm{r}_{\text {hitung }}$ Pearson Correlation dengan $\mathrm{r}_{\text {tabel }}$ Product Moment merupakan kriteria pengujian validitas. Hasil yang diperoleh menunjukkan bahwa kecerdasan intelektual dengan 9 item pernyataan dengan tingkat validitas antara 
0,391-0,822. Kecerdasan emosional dengan 10 item pernyataan dengan tingkat validitas antara 0,430-0,797. Kecerdasan spiritual dengan 12 item pernyataan dengan tingkat validitas antara 0,324-0,790 dan perilaku pegawai 8 pernyataan dengan tingkat validitas antara 0,485-0,732 yang diperoleh dari jawaban 85 orang responden. Hasil semuanya valid karena $r_{\text {hitung }} \geq r_{\text {tabel }}(r=0,211)$ sehingga penelitian ini dapat dilanjutkan.

\section{Uji Reliabilitas}

Hasil pengujian reliabilitas yang dilakukan dapat disimpulkan keempat variabel memiliki Nilai Cronbach's antara
$0,770-0,875 \geq 0,6$ pada taraf nyata alpha $(\alpha)=5 \%$. Artinya dapat dijadikan sebagai alat ukur dalam analisis selanjutnya karena semua item pernyataan yang ada pada instrumen tersebut dinyatakan reliabel.

\section{Pengujian Asumsi Klasik}

Setelah dinyatakan valid dan realitas dapat dilanjutkan dengan melakukan pengujian asumsi klasik, antara lain:

\section{Uji Normalitas}

Secara rinci hasil pengujian normalitas dengan menggunakan Npar Tests (OneSample Kolmogorov-Smirnov Test) dapat dilihat pada tabel berikut :

Tabel 1. Uji Normalitas

\begin{tabular}{|l|r|c|c|}
\hline Model (Variabel) & Asymp. Sig. (2-tailed) & Nilai kritis & Kesimpulan \\
\hline Kecerdasan Intelektual $\left(\mathrm{X}_{1}\right)$, & .798 & $\alpha=0,05$ & $\begin{array}{c}\text { Distribusi } \\
\text { Emosional }\left(\mathrm{X}_{2}\right) \text {, Spiritual }\left(\mathrm{X}_{3}\right) \text { dan }\end{array}$ \\
Perilaku (Y) & & & Normal \\
\hline
\end{tabular}

Sumber : Pengolahan data, 2019

Hasil akhir di atas menunjukkan ke empat variabel berdistribusi normal karena Asymp. Sig. (2-tailed) sebesar 0,798 > 0,05 yang berarti semua variabel memiliki data normal.

\section{Uji Multikolinearitas}

Nilai tolerance dan VIP dalam uji multikolinearitas menjelaskan variabel independen dalam model regresi pada tabel berikut

Tabel 2. Uji Multikolinearitas

\begin{tabular}{|c|c|c|c|}
\hline \multirow{2}{*}{\multicolumn{2}{|c|}{ Model (Variabel) }} & \multicolumn{2}{|c|}{ Collinearity Statistics } \\
\hline & & Tolerance & VIF \\
\hline \multirow{4}{*}{1} & (Constant) & & \\
\hline & Kecerdasan Intelektual $\left(\mathrm{X}_{1}\right)$ & 1.000 & 1.000 \\
\hline & Kecerdasan Emosional $\left(\mathrm{X}_{2}\right)$ & .942 & 1.062 \\
\hline & Kecerdasan Spiritual $\left(\mathrm{X}_{3}\right)$ & .942 & 1.062 \\
\hline
\end{tabular}

Sumber : Pengolahan data, 2019

Nilai Variance Inflation Factor (VIF) pada semua variabel independen berada tidak jauh dari nilai 1 atau lebih kecil dari
10 dan angka tolerance sama dengan 1. Hasil ini masih dalam batas toleransi maka dapat diambil kesimpulan bahwa tidak 
terdapat gejala multikolinearitas, sehingga regresi sah untuk digunakan.

\section{Uji Heteroskedastisitas}

Grafik scatterplot bertujuan mendeteksi ada tidaknya heteroskedastisitas dengan melihat adanya pola tertentu/teratur (bergelombang, melebar kemudian menyempit) serta titik menyebar di atas dan di bawah angka 0 pada sumbu Y

\section{Gambar 1. Hasil Pengujian Heterokedastisitas}

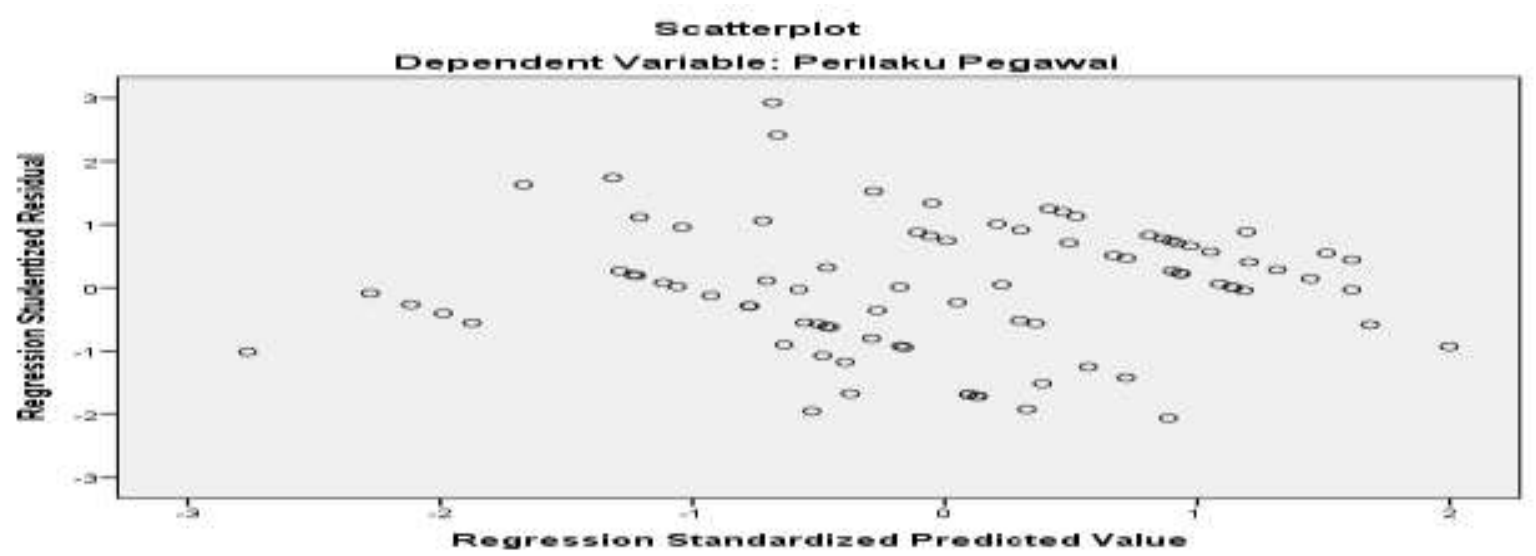

Grafik di atas menunjukkan tidak terjadi heteroskedasitas karena tidak ada pola tertentu yang terbentuk seperti titik yang membentuk suatu pola teratur, selain itu titik- titik menyebar di atas dan di bawah angka 0 pada sumbu Y.

\section{c. Hasil Analisis Data}

Setelah melalui beberapa tahap pengujian, akhirnya data yang ada dapat dilanjutkan analisisnya dengan teknik statistik yaitu analisis regresi seperti yang ditunjukkan tabel berikut.

\section{Regresi Berganda}

Diperoleh hasil olah data yang dilakukan pada regresi berganda sebagai berikut:

Tabel 3. Analisis Regresi Berganda

\begin{tabular}{|c|c|c|c|c|}
\hline \multirow{2}{*}{\multicolumn{2}{|c|}{ Model (Variabel) }} & \multicolumn{2}{|c|}{$\begin{array}{l}\text { Unstandardized } \\
\text { Coefficients }\end{array}$} & \multirow{2}{*}{$\begin{array}{c}\text { Standardized } \\
\text { Coefficients }\end{array}$} \\
\hline & & B & Std. Error & \\
\hline \multirow{4}{*}{1} & (Constant) & .651 & 3.940 & \\
\hline & Kecerdasan Intelektual $\left(\mathrm{X}_{1}\right)$ & .136 & .055 & .187 \\
\hline & Kecerdasan Emosional $\left(\mathrm{X}_{2}\right)$ & .133 & .062 & .168 \\
\hline & Kecerdasan Spiritual $\left(\mathrm{X}_{3}\right)$ & .440 & .053 & .645 \\
\hline
\end{tabular}

Sumber : Pengolahan data, 2019

Hasil regresi berganda dapat disimpulkan dengan persamaan sebagai berikut : $Y=0,651+0,136 X_{1}+0,133 X_{2}+0,440 X_{3}$
Penjelasan persamaan adalah nilai koefisien regresi sebesar 0,651 dapat diartikan bahwa jika kecerdasan intelektual 
$\left(\mathrm{X}_{1}\right)$, kecerdasan emosional $\left(\mathrm{X}_{2}\right)$ dan kecerdasan spiritual $\left(\mathrm{X}_{3}\right)$ sama dengan nol maka kinerja pegawai mengalami peningkatan sebesar 0,651 satu-satuan.

Nilai koefisien regresi 0,136 menunjukkan kecerdasan intelektual berpengaruh positif terhadap perilaku pegawai dan jika mengalami peningkatan sebesar satu satuan maka kinerja pegawai (Y) akan mengalami peningkatan sebesar 0,136 satuan, begitu pula sebaliknya. Selanjutnya nilai koefisien regresi sebesar 0,133 dapat diartikan bahwa kecerdasan emosional $\left(\mathrm{X}_{2}\right)$ berpengaruh positif terhadap perilaku pegawai (Y). Hal ini menunjukkan bahwa apabila kecerdasan emosional mengalami peningkatan sebesar satu-satuan, maka perilaku pegawai mengalami peningkatan sebesar 0,133 satuan, begitu pula sebaliknya. Terakhir, kecerdasan spiritual $\left(\mathrm{X}_{3}\right)$ nilai koefisien regresi sebesar 0,440 dapat diartikan bahwa kecerdasan spiritual $\left(\mathrm{X}_{3}\right)$ berpengaruh positif terhadap perilaku pegawai (Y). Hal ini menunjukkan bahwa apabila kecerdasan emosional mengalami peningkatan sebesar satu-satuan, maka perilaku pegawai mengalami peningkatan sebesar 0,440 satuan, begitu pula sebaliknya.

\section{Koefisien Determinasi}

Nilai 0,535 dari koefisien determinasi $\left(\mathrm{r}^{2}\right)$ berarti kecerdasan intelektual, kecerdasan emosional dan kecerdasan spiritual memberi pengaruh terhadap perilaku pegawai Badan Kependudukan Keluarga Berencana Nasional (BKKBN) Kota Palembang sebesar 53,5\% dan sisanya $(46,5 \%)$ dipengaruhi oleh faktor lain yang tidak termasuk dalam penelitian ini, seperti penghargaan, kompensasi dan lain-lain. Sedangkan koefisien korelasi (R) menunjukkan hubungan yang kuat dan searah sebesar 0,731 ketiga variabel di atas terhadap perilaku pegawai.

\section{Hasil Uji t (Uji Parsial)}

Tabel berikut menyajikan hasil Uji t (parsial) variabel kecerdasan intelektual, kecerdasan emosional dan kecerdasan spiritual:

Tabel 4. Hasil Uji t (Uji Parsial)

\begin{tabular}{|c|c|c|c|c|c|}
\hline \multirow[b]{2}{*}{ Model (Variabel) } & \multicolumn{2}{|c|}{ Uji t } & \multicolumn{2}{|c|}{ Sig. } & \multirow[b]{2}{*}{ Kesimpulan } \\
\hline & $t_{\text {hitung }}$ & $\mathrm{t}_{\text {tabel }}$ & $\begin{array}{c}\text { p- } \\
\text { value }\end{array}$ & $\begin{array}{l}\text { Sig. } \\
(5 \%)\end{array}$ & \\
\hline (Constant) & , 165 & & ,869 & & \\
\hline KecerdasanIntelektual $\left(\mathrm{X}_{1}\right)$ & 2,465 & 1080 & ,016 & 050 & Sangat Berpengaruh \\
\hline Kecerdasan Emosional $\left(\mathrm{X}_{2}\right)$ & 2,155 & 1,909 & ,034 & , & Sangat Berpengaruh \\
\hline Kecerdasan Spiritual $\left(\mathrm{X}_{3}\right)$ & 8,267 & & ,000 & & Sangat Berpengaruh \\
\hline
\end{tabular}

Sumber : Pengolahan data, 2019

Kecerdasan intelektual $\left(\mathrm{X}_{1}\right)$ diperoleh 2,465 > 1,989 dengan p-value (Sig) 0,016 $<0,05$. Menunjukkan bahwa kecerdasan intelektual sangat berpengaruh secara nyata terhadap perilaku pegawai. Hasil ini sesuai dengan penelitian lain yang pernah dilakukan oleh Wulantika dan Buhari
(2015) dan Putri (2016). Dengan kecerdasan yang tinggi seseorang akan lebih mudah menyelesaikan setiap masalah dan menerima tantangan untuk peningkatan kemampuan diri yang pada akhirnya akan berpengaruh terhadap pencapaian kinerja. Cerdas secara 
intelektual mencakup kemampuan nalar, daya tanggap dan kemampuan untuk belajar dengan cepat.

Kecerdasan emosional $\left(\mathrm{X}_{2}\right)$ sebesar 2,155 $>\mathrm{t}_{\text {tabel }}$ 1,989 dan p-value (sig) 0,034 $>0,05$. Ini menunjukkan bahwa kecerdasan emosional $\left(\mathrm{X}_{2}\right)$ berpengaruh terhadap perilaku pegawai. Penelitian serupa pernah dilakukan oleh Kusumawati (2015). Kecerdasan emotional merupakan kompetensi yang mendasar manusia, yang membuat seseorang berbeda mencapai kesuksesan hidupnya. Semakin baik kontrol emosi seseorang akan semakin bijak dalam menghadapi masalah dan membuat keputusan. Seseorang yang bisa memanage emosi bahkan bisa menjadi pemimpin yang baik. Dengan manajemen emosi yang baik ini akan membuat seseorang lebih memahami keadaan di sekitarnya.

Kecerdasan spiritual diperoleh 8,267> $\mathrm{t}_{\text {tabel }} 1,989$ dan p-value (sig) 0,000 > 0,05. Hal ini menunjukkan bahwa kecerdasan spiritual sangat berpengaruh secara nyata terhadap perilaku pegawai. Dari hasil uji t dapat terlihat bahwa kecerdasan spiritual lebih dominan pengaruhnya terhadap perilaku pegawai dibandingkan kedua kecerdasan lainnya. Hasil penelitian serupa dengan penelitian yang dilakukan oleh Haryono dkk (2018) dan Hidayah (2019). Kecerdasan spiritual merupakan kecerdasan tertinggi karena secara efektif dapat memfungsikan sekaligus memanage keduanya.

Biasanya semakin tinggi kecerdasan intelektual seseorang akan semakin tinggi pula ego yang dimiliki, sedangkan kenyataan ini akan berpengaruh pada kecerdasan emosional, artinya jika seseorang mempunyai kecerdasan intelektual lebih tinggi dari orang lain maka akan cenderung bersikap mengunder estimate orang lain. Disinilah fungsi kecerdasan spiritual dibutuhkan karena semakin tinggi kecerdasan spiritual akan semakin baik perilaku diri seseorang termasuk didalamnya dapat mengontrol dua kecerdasan yang lainnya. Dengan kecerdasan spiritual, seseorang akan lebih bisa menghargai dan toleransi terhadap keadaan di lingkungan sekitarnya.

\section{Hasil Uji F (Uji Bersama-sama)}

Tabel berikut ini menyajikan hasil Uji F (Bersama-sama) untuk variabel kecerdasan intelektual, kecerdasan emosional dan kecerdasan spiritual:

Tabel 4. Uji F (Uji Bersama-sama)

ANOVA ${ }^{a}$

\begin{tabular}{|c|c|c|c|c|c|c|c|c|c|}
\hline \multirow{2}{*}{\multicolumn{2}{|c|}{ Model }} & \multirow{2}{*}{$\begin{array}{l}\text { Sum of } \\
\text { Squares }\end{array}$} & \multirow[t]{2}{*}{$\mathrm{df}$} & \multirow{2}{*}{$\begin{array}{l}\text { Mean } \\
\text { Square }\end{array}$} & \multicolumn{2}{|c|}{ Uji F } & \multicolumn{2}{|r|}{ Sig. } & \multirow[t]{2}{*}{ Kesimpulan } \\
\hline & & & & & $\mathrm{F}_{\text {hitung }}$ & $\mathrm{F}_{\text {tabel }}$ & $p$-value & Sig. (5\%) & \\
\hline \multirow{3}{*}{1} & Regression & 438.806 & 3 & 146.269 & \multirow[t]{3}{*}{31,065} & \multirow[t]{3}{*}{2,720} & \multirow[t]{3}{*}{, $000_{b}$} & \multirow[t]{3}{*}{, 050} & \multirow{3}{*}{$\begin{array}{l}\text { Sangat } \\
\text { Berpengaruh }\end{array}$} \\
\hline & Residual & 381.382 & 81 & \multirow[t]{2}{*}{4.708} & & & & & \\
\hline & Total & 820.188 & 84 & & & & & & \\
\hline
\end{tabular}

a. Dependent Variable: Perilaku Pegawai

b. Predictors: (Constant), Kecerdasan Intelektual, Kecerdasan Emosional, Kecerdasan Spiritual Sumber : Pengolahan data, 2019

Nilai $F_{\text {hitung diperoleh sebesar }}$ $(31,065)>\mathrm{F}_{\text {tabel }}(2,720)$ dan nilai $p$-value (Sig) sebesar $0,000<0,05$. Artinya bahwa kecerdasan intelektual $\left(\mathrm{X}_{1}\right)$, kecerdasan emosional $\left(\mathrm{X}_{2}\right)$ dan kecerdasan spiritual $\left(\mathrm{X}_{3}\right)$ sangat berpengaruh secara nyata 
bersama-sama terhadap perilaku pegawai (Y). Pada akhirnya tujuan yang ingin dicapai adalah dengan perilaku yang baik, seorang pegawai akan lebih baik dalam bekerja termasuk akan menjadi lebih amanah, disiplin, dapat menjaga silaturahmi dan mencegah distorsi yang dapat saja terjadi. Hal ini sesuai dengan hasil penelitian yang pernah dilakukan oleh Firdaus dkk (2019). Ketiga kecerdasan di atas saling mendukung karena seorang pegawai membutuhkan kecerdasan intelektual untuk memahami pekerjaan yang diberikan, kecerdasan emosional yang positif bisa membuat pegawai lebih termotivasi dalam bekerja dan memiliki toleransi yang tinggi. Terakhirnya adalah dengan kecerdasan spiritual akan membentuk perilaku pegawai yang lebih berkarakter dan mengontrol timbulnya ego negatif dari kedua kecerdasan yang ada pada diri pegawai.

\section{Kesimpulan dan Saran}

\section{Kesimpulan}

Kesimpulan yang dapat dijabarkan berdasarkan hasil analisis data yang telah dilakukan dalam penelitian ini adalah:
a. Kecerdasan
intelektual
$\left(\mathrm{X}_{1}\right)$
berpengaruh terhadap perilaku
Pegawai Badan Kependudukan dan
Keluarga Berencana Nasional
(BKKBN) Kota Palembang.

b. Kecerdasan emosional $\left(\mathrm{X}_{2}\right)$

berpengaruh terhadap perilaku

Pegawai Badan Kependudukan dan

Keluarga Berencana Nasional

(BKKBN) Kota Palembang.

c. Kecerdasan spiritual $\left(\mathrm{X}_{3}\right)$ sangat berpengaruh terhadap perilaku Pegawai Badan Kependudukan dan Keluarga Berencana Nasional (BKKBN) Kota Palembang. d. Kecerdasan intelektual, kecerdasan emosional dan kecerdasan spiritual secara bersama-sama sangat berpengaruh terhadap perilaku Pegawai Badan Kependudukan dan Keluarga Berencana Nasional (BKKBN) Kota Palembang.

\section{Saran}

Ada beberapa saran yang dapat diberikan untuk mendukung terbentuk perilaku Pegawai Badan Kependudukan dan Keluarga Berencana Nasional (BKKBN) Kota Palembang, yaitu:

a. Walaupun setiap orang telah memiliki kecerdasan intelektual, tetapi masih diperlukan pelatihan, workshop atau bahkan melanjutkan pendidikan yang lebih tinggi, Tujuan yang terpenting dengan mengikuti kegiatan tersebut adalah dapat meningkatkan kemampuan diri pegawai. Selanjutnya dibutuhkan campur tangan pimpinan untuk merealisasikan kegiatan tersebut dan memberikan kesempatan yang sama kepada setiap pegawai.

b. Pada dasarnya kecerdasan emosional sebagai dasar diri manusia yang membentuk perilaku seseorang. Tetapi melihat kondisi sekarang dengan berbagai macam masalah yang timbul terkadang membuat seseorang kurang bisa mengontrol diri. Karena itu perlu dilakukan kegiatan untuk peningkatan kecerdasan emosional, seperti pegawai dilibatkan dalam pembelajaran problem solving. Hal yang diharapkan adalah melihat sejauhmana cara berpikir seorang pegawai ketika menghadapi kesulitan. Pilihan dominan mana yang akan diambil, berpikir secara logis atau bertindak menurut perasaan. 
c. Kecerdasan spiritual yang dimiliki akan menjadi pedoman dalam hidup seseorang. Walaupun kecerdasan spiritual itu berasal dari dalam diri seseorang tetapi dapat diberikan dengan berbagai kegiatan, seperti acara keagamaan untuk menjalin silaturahim atau seminar khusus keagamaan. Pada kegiatan ini bisa menstimulus otak dan pikiran serta menimbulkan kesadaran diri untuk berbuat lebih baik.

\section{Daftar Pustaka}

Carter, Philip. 2010. Soft Competencies SelfTest cetakan pertama. PPM Manajemen. Jakarta.

Daryanto. 2006. Kamus Bahasa Indonesia Lengkap. Apollo. Surabaya.

Firdaus, Adam, RM. Moh. Wispandono, Helmi Buyung. 2019. Pengaruh Kecerdasan Intelektual, Kecerdasan Emosional dan Kecerdasan Spiritual Terhadap Kinerja Pegawai (Studi Pada Kantor Kecamatan Kabupaten Bangkalan). Jurnal eco-entrepreneur. Vol 5, No 1 (2019). Hal:17-32. https://journal.trunojoyo.ac.id/ecoentrepreneur/article/view/5435.

(Akses 27 September 2019).

Ghozali, Imam. 2011. Aplikasi Analisis Multivariate dengan Program IBM SPSS 19. Edisi kelima. Badan Penerbit Universitas Diponegoro. Semarang.

Haryono, Siswoyo, Febry Rosady, Mohd Shamsuri MdSaad. 2018. Effects of Emotional and Spiritual Intelligence on Job Performance among Temporary Nurses at Abdul Riva'i Regional General Hospital, Berau
District, East Kalimantan Province, Indonesia. Management Issues in Healthcare System 4. Hal 42-54 (AIMI Journal) www.aimijournal.com. (Akses 10 des 2019).

Hidayah, Romadhotin. 2019. Pengaruh Kecerdasan Spiritual terhadap Kinerja Karyawan melalui Organizational Citizenship Behavior pada PT PLN (Persero) Area Bojonegoro. Jurnal Ilmu Manajemen Volume 7 Nomor 1 - Jurusan Manajemen Fakultas Ekonomi Universitas Negeri Surabaya. Vol.7, No. 1 (2019). Hal: 58-65. https://jurnalmahasiswa.unesa.ac.id/i ndex.php/jim/article/view/25035.

(Akses 12 September 2019.)

Kusumawati, Yanti. 2015. Pengaruh Kecerdasan Emosional Terhadap Perilaku Pegawai Pada Kantor Badan Perencanaan Pembangunan Daerah (Bappeda) Kota Tanjungpinang Tahun 2015. Hal: 3-30. http://jurnal.umrah.ac.id/wpcontent/uploads/gravity_forms/1-ec6. (Akses 3 Desember 2019).

Prawirosentono S. 2011. Manajemen sumber daya manusia. Kebijakan kinerja karyawan. Yogyakarta.

Priyatno, Duwi. 2018. SPSS 20 Pengolahan Data Terpraktis. Andi offset: Yogyakarta.

Putri, Yeni Sugena. 2016. Pengaruh Kecerdasan Intelektual, Kecerdasan Emosional, Dan Lingkungan Kerja Terhadap Kinerja Karyawan PT. PLN Persero Area Klaten. Jurnal Studi Manajemen dan Organisasi. (13). Hal:88-97. https://media.neliti.com/media/public 
ations/132684-ID-pengaruhkecerdasan-intelektual-kecerdas.pdf . (Akses 27 Sept 2019).

Sujarweni, V. Wiratna. 2014. Metode Penelitian: Lengkap, Praktis, dan Mudah Dipahami. Pustaka Baru Press. Yogyakarta

Sanusi, Anwar. 2014. Metodologi Penelitian Bisnis. Penerbit Salemba Empat. Jakarta.

Sugiyono. 2018. Metode Penelitian Kuantitatif, Kualitatif Dan $R \& D$. Cetakan Kedua puluh tiga. CV. Alfabeta. Bandung.

Sunar, P. 2010. Edisi Lengkap Tes IQ, EQ, dan SQ. Cetakan Pertama. FlashBooks. Jakarta..

Wulantika, Lita, Refi Mayasari Buhari. 2015. The Effect of Spiritual Intelligence on Employees' Empowerment at Pt.Centra Multi Karya. Mediterranean Journal of Social Sciences MCSER Publishing, Rome-Italy Vol 6 No 5 S5. Hal 151-
156.

https://pdfs.semanticscholar.org/f575 /aa82414f4dc5828e7860711429da10 fbcab5.pdf. (Akses 12 Desember 2019).

Zohar, D \& Marshall, I. 2014. Kecerdasan Spiritual (SQ) Memanfaatkan Kecerdasan Spiritual Dalam Berfikir Integralistik dan Holistik Untuk Memaknai Kehidupan. Mizan. Bandung

Zamzam, Fakhry, Havis Aravik, 2016. Manajemen SDM Berbasis Syariah, Bogor: CV. RWTC Success.

Zamzam, F. (2016). Sinergisme Pengaruh Pengembangan Karier Dan Iklim Organisasi Melalui Moderasi Motivasi Kerja Terhadap Implementasi Good Governance Sekretariat DPRD Dalam Wilayah Sumatera Selatan. Jurnal Ecoment Global; Kajian Bisnis dan Manajemen, 1(1), 77-92. 